\title{
The Minimum Wage and Unionization Rates of Low-Wage Workers
}

\author{
Brian Towell \\ University of Tennessee at Martin
}

This paper examines how the minimum wage impacts the incentive to unionize for low-wage workers. I suggest a mechanism whereby increases in the minimum wage effectively crowd out unions, as low-wage workers do not need to collectively bargain for higher wages if the government simply mandates that firms must pay more to each worker. Using data from the Current Population Survey (CPS), I estimate that a $\$ 1$ increase in the minimum wage will decrease unionization rates by 7 percentage points within low-wage occupations. These estimates are robust to controls for spurious time trends.

Keywords: Minimum Wage, Unionization Rates, Low-Wage Workers

\section{INTRODUCTION}

Montgomery (1989) describes the demands of a union as being theoretically similar to a minimum wage constraint, and intuitively unionization is closely related to the minimum wage. Assuming that the minimum wage and the demands of a union are both binding, then under the simplest economic framework either one should increase wages at the expense of greater unemployment. For low-wage workers, for whom the wage demands of a union should be near the minimum wage, unions and a minimum wage may effectively act as substitutes.

As a simple example, consider a worker who can either take a minimum wage job or join a union and receive a job paying higher than minimum wage. Joining the union is not costless; the worker must pay entry fees and annual dues, they face the risk that the union will initiate a strike, they may incur social costs, etc. If the minimum wage is increased, the wage gap between the two options will be reduced or eliminated, thus increasing the likelihood that the costs associated with union membership will outweigh the gains from an increased wage. An increase in the minimum wage may effectively force employers to acquiesce to a portion of what the unions were demanding, reducing the value the union offers to its constituents. Within this framework the minimum wage will have its effectiveness as a poverty fighting tool diminished, as some workers are simply trading higher wages negotiated by a union for higher wages imposed by the government.

While the effects of minimum wage increase on employment have been well explored, evidence on the impact that such increases have on unionization is scarce. In this paper I develop a simple model in which low-wage workers make a unionization decision with the minimum wage acting as their reference point, with increases in the minimum wage increasing the value of this outside option and decreasing the incentive to unionize. This serves to both explain the decline of unions within the U.S. while also providing a new channel through which minimum wage increases may fail to improve the well-being of 
low-wage workers. Using CPS data from 2005 to 2015, I estimate the impact that increases in the minimum wage have on unionization, and I additionally measure how these effects vary depending on the proportion of low-wage workers present in the state-year-occupation combination.

\section{LITERATURE REVIEW}

Whereas Farber (1981) seeks to establish a link between the minimum wage and union wages, this paper is instead focused on the relationship between the minimum wage and unionization rates. While the union premium is a key consideration for unions, it is worth noting that Farber finds no meaningful link between the minimum wage and unionization wages, even when the base union wages are within $10 \%$ of the minimum wage. As such, the observed increases in the minimum wage should generally be reducing the gap between the union and nonunion wages for low skill workers. While there are, of course, other reasons for joining a union (as discussed in Schnabel and Wagner (2003)), wage differential has traditionally been viewed as one of the primary motivations behind union membership.

While linkages between overall union density and the minimum wage have been studied in Aghion et al (2008), there has not been any investigation to how these effects may differ depending on the wage composition of the workers being observed. Minimum wage increases may increase the earnings of higher wage union workers as a result of reduced competition (Western and Rosenfield, 2001), and thus overall union density may increase as a result of a minimum wage increase. By accounting for the wage composition of the observed workers, I am able to determine how minimum wage changes affect the unionization decision amongst the lowest wage workers as well as the population at large. As the minimum wage is ostensibly implemented with the well-being of low-wage workers in mind, it is imperative to isolate the union effects on low-wage workers from the union effects overall so that any gains to low-wage workers can be accurately measured.

The mechanism of minimum wage increases crowding out unionization is also consistent with and useful in explaining the rationality of individual union membership. As noted by Bulkley and Miles (2001), many of the benefits that union members fight for are often felt by free riding non-union members. They argue that joining a union is beneficial to those who wish to influence the union's demands. However, the minimum wage is likely seen as exogenous from an individual's point of view, so when governments are consistently increasing the minimum wage, there is little to be done to influence the union demands, which gives potential union members little incentive to unionize. While unions may be able to influence the minimum wage through lobbying and campaign donations, only the largest unions will be likely to have an impact on state or national level policy, where minimum wages are most commonly set, suggesting that any individual's input into the minimum wage will be relatively small.

\section{MODEL}

The model setup is similar to the one presented in Aghion et al (2008), but unlike Aghion it allows for employment effects to be reduced or even negated, while separating the benefits of minimum wage changes by wage group, allowing the impact on low-wage workers to be isolated.

There is a mass of workers in a low-wage industry equal to one. These workers independently decide whether or not to join a union. A monopsonistic firm represents their only potential employer. There is a single good, which acts as the numeraire. Each worker has a productivity parameter $y$, which is drawn uniformly from the interval $[0,1]$. The productivity of each worker is equal to the sum of their productivity parameter and a parameter $\alpha \in[0,1]$. This productivity, $y+\alpha$, is observable by the firm.

While there are certainly potential non-monetary benefits associated with unionizing, higher earning potential is unquestionably a significant incentive for those who unionize. Further, since the nonmonetary incentives to unionize are unlikely to be strongly correlated with the minimum wage, it is logical to treat monetary concerns and wage differentials as the sole driver of unionization decisions within this context. 
The effect is that each worker receives utility equal to any wages they receive less any costs of unionizing that they incur. Workers are also assumed to be risk neutral. There is a government imposed minimum wage, $W_{M} \in(0,1)$. Consequentially, workers for whom y $\in\left[0, W_{M}-\alpha\right)$ will be unemployed. For $\alpha=0$, there is a 1 to 1 correspondence between increases in the minimum wage and increases in unemployment. For $\alpha=1$, increases in the minimum wage will have no effect on unemployment.

Non-union workers with $y \in\left[W_{M}-\alpha, 1\right]$ receive take it or leave it offers from the firm. As workers have no outside options for employment, the firm simply offers $\mathrm{W}_{\mathrm{M}}$. Workers opting to unionize incur $\operatorname{costs} c>0$, but earn a portion of the output they produce. A union worker earns $\beta y$, where $\beta \in(0,1)$. They earn $W_{M}$ if not in a union. It is assumed that the union, to whatever extent they can affect the cost of unionization, opts to keep $\mathrm{c}$ as low as possible while still being able to function. The effect is that $\mathrm{c}$ is taken as exogenous. The parameter $\alpha$ is production that is kept by the firm regardless of the worker's union status.

Therefore, a worker of type y earns $\mathrm{W}_{\mathrm{M}}$ when not unionized, and $\beta \mathrm{y}-\mathrm{c}$ when unionized, and consequentially will join the union if and only if $\mathrm{y} \geq \frac{W_{M}+c}{\beta}$, meaning that only the highest ability workers will choose to unionize. This implies that the unionization rate is $1-\frac{W_{M}+c}{\beta} \equiv U \cdot \frac{\delta U}{\delta W_{M}}=-\frac{1}{\beta}<0$; the unionization rate decreases as the minimum wage increases. The average skill level of the unionized workers is simply $\frac{1}{2}+\frac{W_{M}+c}{2 \beta} \equiv \bar{y} \cdot \frac{\partial \bar{y}}{\partial W_{M}}=\frac{1}{2 \beta}>0$, so the average skill level of union workers increases as the minimum wage increases.

The total welfare of the low-wage workers in this industry is broken into two parts, the minimum wage multiplied by the number of employed workers, and the sum of rents earned by union workers. The former is simply $\left(1-W_{M}+\alpha\right) W_{M}$. The rents are given by: $\frac{\int_{W_{M}+c}^{1}}{\beta} \beta y-W_{M}-c d y=\frac{\left(-\beta+c+W_{M}\right)^{2}}{2 \beta}$ for $\frac{W_{M}+c}{\beta} \leq 1$. Total welfare is then $\left(1-W_{M}+\alpha\right) W_{M+} \frac{\left(-\beta+c+W_{M}\right)^{2}}{2 \beta} \equiv F$.

The aggregate rents of union workers is trivially seen to be decreasing in the minimum wage since the number of workers unionizing decreases and the value of the outside option for a union worker increases as the minimum wage rises. This implies that $\frac{\partial}{\partial W_{M}} \frac{\left(-\beta+c+W_{M}\right)^{2}}{2 \beta}=\frac{-\beta+c+W_{M}}{\beta} \leq 0 \Rightarrow \mathrm{c} \leq \beta-W_{M}$. This is intuitive since if $\mathrm{c}>\beta-W_{M}$, no worker could find it worthwhile to unionize, and the union effectively would not exist. Because the remaining portion of welfare besides union rents, $\left(1-W_{M}+\alpha\right) W_{M}$, is also decreasing when $W_{M}>\frac{1+\alpha}{2}$, total welfare will fall for any increase in the minimum wage above $\frac{1+\alpha}{2}$. Solving for the welfare maximizing optimal wage yields $\frac{\delta F}{\delta W_{M}}=\frac{c+W_{M}}{\beta}-2 \mathrm{~W}_{M}+\alpha=0$ when $W_{M}=\frac{\alpha \beta+c}{2 \beta-1}$. $\frac{\delta^{2} F}{\delta W_{M}^{2}}=\frac{1}{\beta}-2<0$ for $\beta>1 / 2$. For $\beta \leq 1 / 2$ the optimal minimum wage is $W_{M}=\beta$-c, as the derivative of welfare is strictly increasing in $W_{M}$ over this range, and thus the constraint $\mathrm{c} \leq \beta-W_{M}$ must bind. It is trivial to confirm that for the case of $\beta \leq 1 / 2, W_{M}<1 / 2$. When considering $\beta>1 / 2$, note that maximizing $\frac{\alpha \beta+c}{2 \beta-1}$ subject to $c \leq \beta-W_{M} \Rightarrow c \leq \beta-\frac{\alpha \beta+c}{2 \beta-1} \Rightarrow c \leq \beta-\frac{1-\alpha}{2}$ has its constraint bind and thus the maximal value of the optimal minimum wage is $\frac{\left(\beta-\frac{1}{2}\right) *(1+\alpha)}{2 \beta-1}$. For the case of $\alpha=0$, this places a universal upper bound on the optimal minimum wage of $1 / 2$. For $\alpha>0$, the upper bound on the minimum wage depends on $\beta$, and will exceed $1 / 2$ when $\beta>1 / 2$. To summarize, $W_{M}^{*}=\left\{\begin{array}{l}\frac{\alpha \beta+c}{2 \beta-1} \text { for } \beta>\frac{1}{2} \\ \beta-c \text { for } \beta \leq \frac{1}{2}\end{array}\right.$ where $W_{M}^{*}$ is the minimum wage that maximizes welfare amongst low-wage employees. The optimal minimum wage depends on the 
bargaining power that union workers have and the cost of unionization. Minimum wages that are set without taking these factors into account will fail to maximize the well-being of low-wage workers. Note that $\frac{\partial^{2} U}{\partial W_{M} \partial \beta}=\frac{1}{\beta^{2}}>0$. Thus, the higher the union premium that is offered, the less responsive workers are to changes in the minimum wage.

It is worth noting that under this framework, the firm could offer an amount above the minimum wage to non-union members in order to reduce the amount of employees who decide to unionize, but this strategy will never be profitable. The firm's profits can be split into union and non-union profits. Each union member generates a profit of $(1-\beta) y+\alpha$ for the firm. Each non-union member generates a profit of $y+\alpha-W_{M}$ for the firm. The firm's total profits, denoted by $\Pi$, can then be given by integrating each of these profit equations separately over the relevant ranges of $y$ and adding the two together. This gives $\Pi=\frac{-\beta^{2}+c^{2}-W_{M}^{2}+\beta\left(1+\alpha^{2}-2 \alpha\left(W_{M}-1\right)+W_{M}^{2}\right)}{2 \beta}$. Note that $\frac{\delta \Pi}{\delta W_{M}}=-\alpha-\frac{W_{M}}{\beta}+W_{M}<0$ since $\beta<1$. Therefore, the firm's profits are strictly decreasing in the wages paid to non-union members, and so the firm will always pay non-union members the minimum wage.

\section{METHODOLOGY}

In order to test the primary model result empirically, that low-wage workers will be less likely to unionize when the minimum wage is increased, the simplest specification is

$\mathrm{UR}_{\mathrm{ijt}}=\beta_{0}+\beta_{1} \mathrm{MW}_{\mathrm{ijt}}+\mathrm{u}_{\mathrm{ijt}}+\theta_{\mathrm{i}}+\gamma_{\mathrm{j}}+\eta_{\mathrm{t}}$

where UR denotes the unionization rate, MW the nominal minimum wage, $\mathrm{i}$ an index for state, $\mathrm{j}$ an index for occupation, and $t$ an index for time.

The robustness of such results is threatened by a high likelihood of spurious correlation. Given the decline that unions have faced in recent years, and the fact that minimum wages have never decreased nominally, any relationship found would be highly suspect since other changes to policy or social norms may be the only drivers of changing unionization rates, without minimum wages providing any causal effect.

In order to address this threat, I calculate the regression using both real and nominal wages. As the nominal minimum wage doesn't change in most years for most states, the real minimum wage often falls, and this can be used to help isolate the causal impact the minimum wage has from any trends that are simply simultaneously occurring over time. If the results are similar for each regression, then it can be inferred that the correlation is not the result of some synchronized time trend affecting both the minimum wage and unionization rates.

Comparing the impact the minimum wage has on unionization rates in observations with differing proportions of low-wage workers also clarifies the situation. The effect of a minimum wage increase on high-wage workers is expected to either be zero, as the minimum wage is a non-binding constraint for such workers, or positive, as minimum wage increases may serve to reduce the competition that union members face.

The inclusion of year fixed effects and state specific linear and quadratic trends should also help to isolate causal effects. Finally, a counterfactual estimate is constructed, predicting low-wage unionization rates for a fixed minimum wage.

A secondary threat may be present if workers are not immediately responsive to changes in the minimum wage. If workers are slow to gauge the relative costs and benefits of their union membership, this simple regression will be unlikely to produce robust results, since it implicitly presumes that workers observe a minimum wage change and reevaluate their union status within the same year. If the real decision-making process takes longer than this for some workers, the results will likely attenuate the true impact. To address this issue, lagged values of the minimum wage are regressed against unionization rates. 
In addition to testing the reaction of unionization rates to changes in the minimum wage, the additional model assumptions are also tested. The model predicts that a higher minimum wage will cause the average skill level of low-wage union workers to increase; this is measured empirically by regressing the percentage of workers who have graduated from college in such unions against the minimum wage. The model also predicts that an increased union premium will negate some the decline in union membership that an increased minimum wage causes. This is tested by running the initial regression separately for those earning a below average union premium and those earning an above average union premium, with the union premium taken simply as the ratio of wages for union to non-union workers within an observation.

\section{RESULTS}

All data utilized is from the CPS Outgoing Rotation Group, with observations from years 2005-2015. Workers were included if they were employed in a job paying by the hour and reported positive hourly earnings. Each observation is a state-year-occupation combination, with the unionization rate calculated for each of these observations from each individual's response as to whether or not they are a union member.

To test the impact that the minimum wage has on union membership rates, Table 1 features results from the regression:

$$
\mathrm{UR}_{\mathrm{ijt}}=\beta_{0}+\beta_{1} \mathrm{MW}_{\mathrm{it}}+\beta_{2} \mathrm{Wx}_{\mathrm{ijt}}+\beta_{3} \mathrm{MW}_{\mathrm{it}} \mathrm{Wx}_{\mathrm{ijt}}+\varepsilon_{\mathrm{ijt}}
$$

where MW is the minimum wage, and $\mathrm{Wx}$ is the portion of workers whose hourly wage is within $\mathrm{x}$ percent of the minimum wage for $\mathrm{x}=5,10,20$, and 30 respectively. Controls for state, year and occupation fixed effects, state specific linear and quadratic trends, average education level, average age, average number of children, percentage of married people, percentage of veterans, percentage of people living in a metropolitan area, percentage of female workers, and percentage of black workers were included but not reported.

\section{TABLE 1}

\section{UNIONIZATION RATES}

\begin{tabular}{|c|c|c|c|c|}
\hline & 1 & 2 & 3 & 4 \\
\hline MW & $\begin{array}{l}0.007 \\
(0.002)^{* * *}\end{array}$ & $\begin{array}{l}0.008 \\
(0.002)^{* * *}\end{array}$ & $\begin{array}{l}0.011 \\
(0.002)^{* * *}\end{array}$ & $\begin{array}{l}0.013 \\
(0.002)^{* * * *}\end{array}$ \\
\hline MW*W5 & $\begin{array}{l}-0.035 \\
(0.003)^{* * *}\end{array}$ & & & \\
\hline$M W * W 10$ & & $\begin{array}{l}-0.030 \\
(0.002)^{* * *}\end{array}$ & & \\
\hline MW*W20 & & & $\begin{array}{l}-0.028 \\
(0.002)^{* * *}\end{array}$ & \\
\hline$M W * W 30$ & & & & $\begin{array}{l}-0.026 \\
(0.002)^{* * *}\end{array}$ \\
\hline$R^{2}$ & 0.49 & 0.49 & 0.49 & 0.49 \\
\hline$N$ & 149,390 & 149,390 & 149,390 & 149,390 \\
\hline
\end{tabular}

Notes: Standard errors in parentheses. Observations are state-year-occupation combinations. Dependent variable is the percentage of workers who are union members. Controls included for average education level, percentage of workers who are female, percentage of workers who are black, average age, percentage of workers who are married, percentage of workers who are veterans, average number of children, percentage of workers in a metropolitan area, year fixed effects, state fixed effects, occupation fixed effects, and state specific linear and quadratic trends. Wx denotes the percentage of workers earning within $\mathrm{x} \%$ of the prevailing minimum wage and is also included as an individual variable in each regression. 
To isolate the impact on low-wage occupations, the minimum wage is interacted the percentage of workers within the observation whose hourly wage is within 5 percent, 10 percent, 20 percent or 30 percent of the minimum wage. Regardless of the specification used, the net effect of a minimum wage increase on unionization rates is negative in the extreme case that all workers in the observation qualify as being low-wage workers, with a $\$ 1$ increase in the minimum wage expected to decrease unionization by between .2 percent and 1 percent in such cases. For specifications 1-4 respectively, 2.8 percent, 2.6 percent, 2.8 percent, and 2.9 percent of observations featured both a positive unionization rate and enough low-wage workers for the net effect of a minimum wage increase to be negative. For comparison purposes, the BLS estimates that 3.3 percent of wage and salary workers earned the prevailing minimum wage in 2015. For observations featuring both positive unionization and enough low-wage workers to imply a net negative effect on unionization rates under specification 1, approximately $39 \%$ of workers qualified as low-wage workers. This suggests that $\$ 1$ increase in the minimum wage would decrease unionization rates for these workers by .7 percentage points.

The regression was also repeated using higher thresholds to define a low-wage worker. Defining a low-wage worker as one earning within $100 \%$ of the minimum wage, the net effect of a minimum wage change on unionization rates was zero for observations with all workers earning less than the threshold.

Table 2 features results from the regression in column 6, with preceding columns omitting certain terms, where MW is the minimum wage and W5 is the portion of workers whose hourly earnings are with within 5 percent of minimum wage. W5 terms for the appropriate period were also included. The controls utilized are identical to those in Table 1. The results are largely consistent with those of Table 1, column 1. In each specification the eventual impact on the unionization rate is similar to the net effect felt with no lags included.

$\mathrm{UR}_{\mathrm{ijt}}=\beta_{0}+\beta_{1} \mathrm{MW}_{\mathrm{it}}+\beta_{2} \mathrm{MW}_{\mathrm{it}} \mathrm{W} 5_{\mathrm{ijt}}+\beta_{3} \mathrm{MW}_{\mathrm{it}-1}+\beta_{4} \mathrm{MW}_{\mathrm{it}-1} \mathrm{~W} 5_{\mathrm{ijt}-1}+\beta_{5} \mathrm{MW}_{\mathrm{it}-2}+\beta_{6} \mathrm{MW}_{\mathrm{it}-2} \mathrm{~W} 5_{\mathrm{ijt}-2}+\varepsilon_{\mathrm{ijt}}$

Table 2 also serves as a check against possible reverse causality. Legislatures who observe a decrease in unionization rates for low-wage workers may decide to increase the minimum wage as a method of replacing the wage effects a union offers. However, in every specification of table 2 there are deunionization effects felt in the years following minimum wage increases. While an increase in the minimum wage could impact unionization decisions in the years following, legislatures cannot feasibly be making minimum wage decisions based on changes in unionization rates that have not yet been realized. Additionally, looking at state-years featuring a minimum wage increase, approximately $56 \%$ of them followed a two year period featuring an overall decrease in state unionization. Given that minimum wage increases are nearly evenly split as following unionization increases and decreases, combined with the general decline of unionization rates over the years, it does not appear that legislatures are using minimum wage increases to counteract decreased unionization on a wide scale. 


\section{TABLE 2}

UNIONIZATION RATES WITH LAGS

\begin{tabular}{|c|c|c|c|c|c|c|}
\hline & 1 & 2 & 3 & 4 & 5 & 6 \\
\hline MW & & & & $\begin{array}{l}0.008 \\
(0.002) * * *\end{array}$ & $\begin{array}{l}0.013 \\
(0.003) * * *\end{array}$ & $\begin{array}{l}0.012 \\
(0.003) * * *\end{array}$ \\
\hline MW*W5 & & & & $\begin{array}{l}-0.037 \\
(0.004)^{* * *}\end{array}$ & $\begin{array}{l}-0.048 \\
(0.004)^{* * *}\end{array}$ & $\begin{array}{l}-0.045 \\
(0.005) * * *\end{array}$ \\
\hline $\mathbf{M W}_{\mathrm{t}-1}$ & $\begin{array}{l}0.007 \\
(0.002) * * *\end{array}$ & & $\begin{array}{l}0.004 \\
(0.003)\end{array}$ & $\begin{array}{l}0.005 \\
(0.002)^{* * *}\end{array}$ & & $\begin{array}{l}0.002 \\
(0.003)\end{array}$ \\
\hline $\mathrm{MW}_{\mathrm{t}-1} * \mathrm{~W} 5$ & $\begin{array}{l}-0.035 \\
(0.003)^{* * *}\end{array}$ & & $\begin{array}{l}-0.029 \\
(0.005)^{* * *}\end{array}$ & $\begin{array}{l}-0.011 \\
(0.004)^{* * *}\end{array}$ & & $\begin{array}{l}-0.007 \\
(0.005)\end{array}$ \\
\hline $\mathbf{M W}_{\mathrm{t}-2}$ & & $\begin{array}{l}0.004 \\
(0.002)^{*}\end{array}$ & $\begin{array}{l}0.004 \\
(0.002)^{*}\end{array}$ & & $\begin{array}{l}0.004 \\
(0.002)^{*}\end{array}$ & $\begin{array}{l}0.004 \\
(0.002)\end{array}$ \\
\hline $\mathbf{M W}_{\mathrm{t}-2} * \mathbf{W 5}$ & & $\begin{array}{l}-0.038 \\
(0.003)^{* * *}\end{array}$ & $\begin{array}{l}-0.021 \\
(0.004)^{* * *}\end{array}$ & & $\begin{array}{l}-0.015 \\
(0.004)^{* * *}\end{array}$ & $\begin{array}{l}-0.012 \\
(0.005)^{* * *}\end{array}$ \\
\hline$R^{2}$ & 0.51 & 0.51 & 0.53 & 0.51 & 0.51 & 0.53 \\
\hline$N$ & 112,074 & 99,287 & 88,914 & 112,074 & 99,287 & 88,914 \\
\hline
\end{tabular}

Notes: Standard errors in parentheses. Observations are state-year-occupation combinations. Dependent variable is the percentage of workers who are union members. Controls included for average education level, percentage of workers who are female, percentage of workers who are black, average age, percentage of workers who are married, percentage of workers who are veterans, average number of children, percentage of workers in a metropolitan area, year fixed effects, state fixed effects, occupation fixed effects, and state specific linear and quadratic trends. W5 denotes the percentage of workers earning within $5 \%$ of the prevailing minimum wage and is also included as an individual variable in each regression.

Table 3 tests the model's implication that increases in the minimum wage will increase the average skill level of unionized low-wage workers. The results are from the regression with fixed effects included, but not reported, for year, state, and occupation as well as state-specific linear and quadratic trends. AUC is the proportion of observed workers who have graduated from college, and MW is the minimum wage. Observations were considered low-wage if at least $5 \%$ of workers earned within $5 \%$ of the minimum wage in Column 1, with the threshold raised to 15 and 25 percent of workers earning within $5 \%$ of the minimum wage in columns 2 and 3 respectively. The anticipated positive relationship is found between the minimum wage and skill level of low-wage union members. The results coincide with the model, and each specification suggests that a $\$ 1$ increase in the minimum wage will increase the percentage of unionized workers in low-wage observations who have graduated from college by $2.6-10.8$ percentage points. This suggests that as the minimum wage increases, it is predominantly uneducated workers who are leaving their union.

$$
\mathrm{AUC}_{\mathrm{ijt}}=\beta_{0}+\beta_{1} \mathrm{MW}_{\mathrm{it}}+\varepsilon_{\mathrm{ijt}}
$$


TABLE 3

EDUCATION LEVEL OF UNIONIZED WORKERS

\begin{tabular}{llll}
\hline & $\mathbf{1}$ & $\mathbf{2}$ & $\mathbf{3}$ \\
\hline $\mathbf{M W}$ & 0.026 & 0.074 & 0.108 \\
& $(0.016)$ & $(0.026) * * *$ & $(0.037) * * *$ \\
$R^{2}$ & 0.24 & 0.23 & 0.27 \\
$N$ & 11,381 & 5,769 & 3,134 \\
\hline$* p<0.1 ; * * p<0.05 ; * * * p<0.01$ & &
\end{tabular}

Notes: Standard errors in parentheses. Observations are state-year-occupation combinations. Dependent variable is the percentage of union workers who have graduated from college. Controls included for year fixed effects, state fixed effects, occupation fixed effects, and state specific linear and quadratic trends. Column 1 includes an observation if at least $5 \%$ of workers earn within $5 \%$ of the minimum wage. Column 2 includes an observation if at least $15 \%$ of workers earn within $5 \%$ of the minimum wage. Column 3 includes an observation if at least $5 \%$ of workers earn within $25 \%$ of the minimum wage.

Table 4 analyzes the impact that the union premium plays in determining how sensitive low-wage workers are to changes in the minimum wage when making unionization decisions. The regression is identical to column 1 of table 1, except that in column 1 only observations with a below average union premium are considered, and only those with an above average union premium are considered in table 2.

TABLE 4 UNIONIZATION RATES SEPARATED BY UNION PREMIUM

\begin{tabular}{lll}
\hline & $\mathbf{1}$ & $\mathbf{2}$ \\
\hline MW & 0.014 & 0.006 \\
& $(0.003)^{* * * *}$ & $(0.004)$ \\
MW*W5 & -0.038 & -0.011 \\
& $(0.006)^{* * *}$ & $(0.008)$ \\
$R^{2}$ & 0.62 & 0.64 \\
$N$ & 24,912 & 18,195 \\
\hline$* p<0.1 ; * * p<0.05 ; * * * p<0.01$ & &
\end{tabular}

Notes: Standard errors in parentheses. Observations are state-year-occupation combinations. Dependent variable is the percentage of workers who are union members. Controls included for average education level, percentage of workers who are female, percentage of workers who are black, average age, percentage of workers who are married, percentage of workers who are veterans, average number of children, percentage of workers in a metropolitan area, year fixed effects, state fixed effects, occupation fixed effects, and state specific linear and quadratic trends. W5 denotes the percentage of workers earning within $5 \%$ of the prevailing minimum wage and is also included as an individual variable in each regression. Column 1 includes only observations with a below average union premium. Column 2 includes only observations with an above average union premium.

The union premium is simply calculated as the ratio of the average union wage to the average nonunion wage, and only observations with both union and non-union workers were considered. The average union premium was approximately 1.29. As the model predicts, workers earning a larger union premium are less responsive to changes in the minimum wage.

Table 5 repeats the steps of Table 1, but adjusts wages for inflation. Defining low-wage workers as earning within 5, 10, 20 and 30 percent of the minimum wage resulted in, respectively, 3.8 percent, 3.9 percent, 4.4 percent and 4.6 percent of observations having both positive unionization rates and enough low-wage workers to imply that minimum wage increases had a net negative effect on unionization. The 
results, as in Table 1, suggest that increases in the minimum wage are crowding low-wage workers out of unions.

TABLE 5

UNIONIZATION RATES USING REAL MINIMUM WAGE

\begin{tabular}{|c|c|c|c|c|}
\hline & 1 & 2 & 3 & 4 \\
\hline RMW & $\begin{array}{l}0.010 \\
(0.002) * * *\end{array}$ & $\begin{array}{l}0.011 \\
(0.002) * * *\end{array}$ & $\begin{array}{l}0.015 \\
(0.002) * * *\end{array}$ & $\begin{array}{l}0.018 \\
(0.002) * * *\end{array}$ \\
\hline RMW*W5 & $\begin{array}{l}-0.065 \\
(0.003)^{* * *}\end{array}$ & & & \\
\hline RMW*W10 & & $\begin{array}{l}-0.057 \\
(0.003)^{* * *}\end{array}$ & & \\
\hline RMW*W20 & & & $\begin{array}{l}-0.052 \\
(0.002)^{* * *}\end{array}$ & \\
\hline RMW*W30 & & & & $\begin{array}{l}-0.048 \\
(0.002)^{* * *}\end{array}$ \\
\hline$R^{2}$ & 0.49 & 0.49 & 0.49 & 0.49 \\
\hline$N$ & 149,390 & 149,390 & 149,390 & 149,390 \\
\hline
\end{tabular}

Notes: Standard errors in parentheses. Observations are state-year-occupation combinations. Dependent variable is the percentage of workers who are union members. Controls included for average education level, percentage of workers who are female, percentage of workers who are black, average age, percentage of workers who are married, percentage of workers who are veterans, average number of children, percentage of workers in a metropolitan area, year fixed effects, state fixed effects, occupation fixed effects, and state specific linear and quadratic trends. Wx denotes the percentage of workers earning within $\mathrm{x} \%$ of the prevailing minimum wage and is also included as an individual variable in each regression.

Using the specification in column 1, observations with both positive unionization rates and enough low-wage workers to imply a net decrease in unionization when the minimum wage increases have $30.8 \%$ of workers earning within $5 \%$ of the minimum wage. This implies that a $\$ 1$ increase in the minimum wage will decrease unionization rates for such observations by 1 percentage point.

If a state sees a significant decrease in unionization when the minimum wage increases, this may also alter the employment effect associated with the minimum wage increase. Under the most basic economic framework, a decrease in unionization would be expected to negate some of the employment effects associated with a minimum wage increase. Table 6 analyzes this relationship, running the regression in column 1. LowWageUnion is defined as the unionization rate for workers within the state who belong to a year-state-occupation combination with at least $20 \%$ of workers earning within $5 \%$ of the minimum wage. This cutoff was chosen as it is the ratio of low-wage workers needed to imply a net unionization decrease in column 1 of table 1 .

$\Delta \log \left(\right.$ Unemployment $\left._{\mathrm{st}}\right)=$

$\beta_{0}+\beta_{1} \Delta \log \left(\mathrm{MW}_{\mathrm{st}}\right)+\beta_{2}$ LowWageUnion $_{\mathrm{st}}+\beta_{3} \Delta \log \left(\mathrm{MW}_{\mathrm{st}}\right) *$ LowWageUnion $_{\mathrm{st}}+\varepsilon_{\mathrm{st}}$ 
TABLE 6

LOW-WAGE UNIONIZATION AND MINIMUM WAGE EMPLOYMENT EFFECTS

\begin{tabular}{llll}
\hline & $\mathbf{1}$ & $\mathbf{2}$ & $\mathbf{3}$ \\
\hline $\log \left(\mathbf{M W}_{\mathbf{t}}\right)-\log \left(\mathbf{M W}_{\mathbf{t}-\mathbf{1}}\right)$ & 1.441 & 0.086 & -0.190 \\
& $(0.212)^{* * *}$ & $(0.199)$ & $(0.195)$ \\
LowWageUnion & 0.937 & 0.142 & 0.555 \\
& $(0.261)^{* * * *}$ & $(0.283)$ & $(0.427)$ \\
LowWageUnion* & -12.479 & -8.086 & -6.316 \\
{$\left[\log \left(\mathbf{M W}_{\mathbf{t}}\right)-\mathbf{L o g}\left(\mathbf{M W}_{\mathrm{t}-1}\right)\right]$} & $(3.700)^{* * * *}$ & $(3.106)^{* * *}$ & $(3.077)^{* *}$ \\
& & & $\mathrm{Y}$ \\
State Controls & $\mathrm{N}$ & $\mathrm{Y}$ & $\mathrm{Y}$ \\
State Fixed Effects & $\mathrm{N}$ & $\mathrm{N}$ & 0.51 \\
$R^{2}$ & 0.10 & 0.40 & 510 \\
$N$ & 510 & 510 &
\end{tabular}

Notes: Standard errors in parentheses. Observations are state-year combinations. The dependent variable is the log of unemployment in period $t$ minus the log of unemployment in period $t-1$. State controls include the percentage of workers in the state who graduated from high school and college, the percentage of workers who are black, married, veterans, and female, the average number of children for employees, the average age of employees, the percentage of workers earning within $5 \%$ of the minimum wage, and the percentage of workers living within a metropolitan area. LowWageUnion is the percentage of workers belonging to a union in year-state-occupation combinations with at least $20 \%$ of members earning within $5 \%$ of the minimum wage.

It is expected that states with a higher percentage of low-wage workers unionized will have a lesser employment effect from a minimum wage increase since they will have a greater capacity to deunionize when the minimum wage increases. Columns 2 and 3 add additional controls and state fixed effects respectively. In all specifications, the expected level of unemployment after a minimum wage increase is lower when there is a greater level of low-wage unionization. The standard deviation for low-wage unionization rates was approximately .04 across state-years, so column 3 suggests that a state facing a $10 \%$ increase in the minimum wage would face approximately $2.5 \%$ less of an unemployment increase if its low-wage unionization rate were one standard deviation higher.

Figure 1 compares the actual unionization rates across observations with at least $25 \%$ of workers earning within $5 \%$ of the minimum wage with an estimate of a counterfactual case where minimum wages stay constant at 2005 levels. This is done by repeating the steps of the regression in table 1 and adjusting the fitted unionization value to reflect the 2005 minimum wage level. The average predicted unionization level is taken for each year and compared to the actual unionization rate for qualifying observations in that year. In 2015 it is estimated that increases in the minimum wage since 2005 have contributed to a 6 percentage points decrease in the unionization rate for these workers. 
FIGURE 1

ACTUAL AND PREDICTED UNIONIZATION RATES

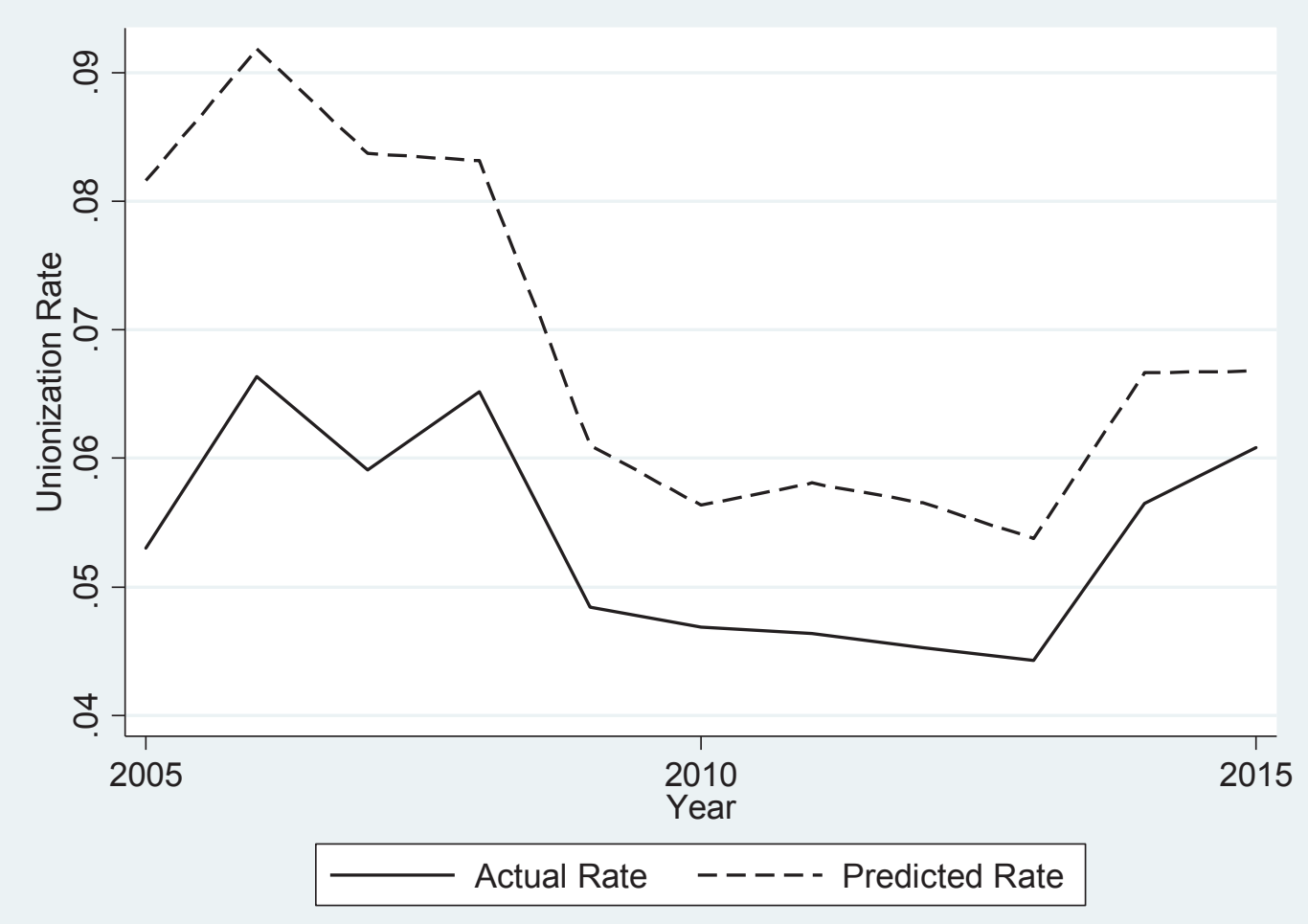

\section{SUMMARY}

In this paper, I find evidence suggesting that unionization rates of low-wage workers are negatively correlated with the minimum wage. I estimate that a \$1 increase in the minimum wage will decrease unionization rates of low-wage workers by approximately .7 percentage points. It appears that many workers merely substitute collectively bargained wage increases for government imposed wage increases when the minimum wage is increased, which serves to partially explain the decline in unionization in the U.S. as well as provide a potential channel through which minimum wage increases may fail to improve the well-being of those who they are ostensibly meant to help, the workers who earn the lowest wages. Potential improvements on the empirical results could be made if more union characteristics could be controlled for, such as the level of dues and fees collected or the amount of strike activity. These are both significant costs of unionizing, and therefore barriers to unionization that are likely only partially captured by the utilized fixed effects. 


\section{REFERENCES}

Aghion, P., Algan, Y., \& Cahuc, P. (2008). Can policy interact with culture? Minimum wage and the quality of labor relations. IZA Discussion Paper Series, No. 3680.

Bulkley, G., \& Myles, G. (2001). Individually rational union membership. European Journal of Political Economy, 17(1), 117-137.

Farber, H. (1981). Union wages and the minimum wage. Minimum Wage Study Commission.

Montgomery, E. (1989). Employment and unemployment effects of unions. Journal of Labor Economics, 7(2), 170-190.

Schnabel, C., \& Wagner, J. (2003). Determinants of trade union membership in Western Germany: Evidence from Micro Data, 1980-2000. IZA Discussion Paper Series, No. 708.

Western, B., \& Rosenfeld, J. (2011). Unions, norms, and the rise in U.S. wage inequality. American Sociological Review, 76(4), 513-537. 